\title{
Habitat associations and seasonal activity of carabid beetles (Coleoptera: Carabidae) in Dongling Mountain, North China
}

\author{
Xiao-Dong Yu, Tian-Hong Luo \& Hong-Zhang Zhou*
}

Yu, X.-D., Luo, T.-H. \& Zhou, H.-Z. 2006: Habitat associations and seasonal activity of carabid beetles (Coleoptera: Carabidae) in Dongling Mountain, North China. — Entomol. Fennica 17: 174-183.

Habitat distribution and seasonal occurrence of carabid beetles were determined using pitfall traps in 1999 and 2000 in the temperate forest zone of the Dongling Mountain, North China. Eight sites differing in vegetation and moisture were selected so as to represent four habitat types. Carabid assemblages of the six forested habitats (lowland, upland and coppice) were more similar to each other than to the two shrub assemblages. Lowland forest had the highest species richness, and coppice forest had the highest diversity $\left(H^{\prime}\right)$ and equitability $(J)$. Of the 41 species caught, the 18 most abundant species were divided into four distribution types: habitat generalists, forest generalists, forest specialists, and shrub (or coppice) specialists. Mean catches of all beetles showed clear peaks from May to August in nearly all habitats. The catches of the six most abundant species were more or less positively correlated during the two study years, suggesting their similar habitat preferences.

X.-D. Yu, T.-H. Luo \& H.-Z. Zhou*, Institute of Zoology, Chinese Academy of Sciences, Beijing 100080, P. R. China; *correspondent author's e-mail: zhouhz @ioz.ac.cn

X.-D. Yu \& T.-H. Luo, Graduate School, Chinese Academy of Sciences, Beijing 100039, P. R. China

Received 8 June 2005, accepted 22 November 2005

\section{Introduction}

The heterogeneous distribution of resources and abiotic conditions affect the spatial and temporal occurrence of carabid beetles (Wiens 1976, Niemelä \& Halme 1992, Niemelä et al. 1992). Associated with several scales of environmental heterogeneity, species responses may be determined by different factors at the various levels of environmental heterogeneity (Addicott et al. 1987). Carabid beetles show a non-random spatial distribution both within and between habitats (Lindroth 1961-1969, Thiele 1977, Wiens 1989, Epstein \& Kulman 1990, Niemelä et al. 1988,
1992, Niemelä \& Halme 1992). Previous studies have suggested that the distributions of carabids are generally structured with respect to microhabitat patches within forests and even within the movement range of individual beetles (Wallin \& Ekbom 1988, Epstein \& Kulman 1990, Niemelä et al. 1988, 1992, Niemelä \& Halme 1992, Niemelä \& Spence 1994).

There exist many quantitative studies on the distribution of carabid beetles in various habitats in Europe and North America, and associations of particular species with broad habitat categories, such as "forests" or "fields", have been established generally for carabids in the context of tax- 
onomic and faunistic work (Lindroth 1961-1969, Thiele 1977, Esau \& Peters 1975, Liebherr \& Marhar 1979, Epstein \& Kulman 1990, Niemelä \& Halme 1992, Niemelä et al. 1992). However, for Chinese carabid species quantitative studies of the whole assemblages are scarce, except for a few studies on the ecology of agricultural environments or taxonomy (Yu et al. 1980, Huang 1990, Hu et al. 1998). Studies of assemblages of forest carabids are particularly rare, although some excellent studies on habitat distribution and molecular evolution, using particular species or groups of congeners, do exist (Kim et al. 2000, Yu et al. 2001, 2002, 2004, Su et al. 2003, 2004).

The excessive land use during recent decades has resulted in a drastic decrease in the total forest cover and an increasingly skewed size distribution of forest remnants. This fragmentation process accounts for much of the loss of biodiversity and rates of species extinction all over the world (Didham et al. 1996). The temperate forest zone, a large phytogeographical zone in China, has historically been one of the most extensive forests within China. However, at present that area is heavily impacted by humans.

Compared with studies done at the same latitudes world-wide, North Chinese studies on the assemblages of carabid beetles in the temperate deciduous broad-leaved forests are rare, and some of the species may have become extinct before the rise of concern. The purpose of the present study was to gain basic ecological knowledge on factors affecting carabid beetle abundances. We examined the spatial and temporal distribution of carabids in temperate forests of North China, and described the species composition of carabid assemblages over multiple habitat types.

\section{Material and methods}

\subsection{Study site}

This study was conducted at the Dongling Mountain $\left(40^{\circ} 00^{\prime} \mathrm{N}, 115^{\circ} 26^{\prime} \mathrm{E}\right)$, which is a part of the Taihang Mountain Ranges near Beijing, North China. The study area is associated with mountain brown soil and temperate monsoon climate with average annual temperature being $+4.8^{\circ} \mathrm{C}$ (January $-10.1^{\circ} \mathrm{C}$, July $+18.3^{\circ} \mathrm{C}$ ). The annual precipitation amounts to $611.9 \mathrm{~mm}, 78 \%$ of the annual rainfall occurring between June and August (Chen \& Huang 1997).

Eight sites were sampled, each representing vegetation types commonly found in the area. Five sites were located at Beijing Forestry Ecosystem Research Station (BFERS, ca. 114 km west of Beijing), at $800-1,600 \mathrm{~m}$ a.s.l. At that area, oak forests (Quercus liaotungensis) represent the most extensive forest type, a native upland forest association. In some lowland and valley sites, walnut forests (Juglans mandshurica) and mixed broad-leaved forests represent the typical native forests, the latter being mostly dominated by Acer mono, Betula dahurica, Juglans mandshurica, Fraxinus rhynchophylla, Populus davidiana, Quercus liaotungensis, Sorbus pauhuashanensis, Tilia mongolica, T. mandshurica, etc. In addition, in some areas where the native forests have been logged 30-40 years ago, nonnative coniferous plantations of larch (Larix principis-rupprechtii) and pine (Pinus tabulaeformis) dominate. At the time of the study, all of the five forest patches within the BFERS area had a closed canopy with tree height of 8-15 $\mathrm{m}$ (up to $20 \mathrm{~m}$ ). The three other sites were located at Liyuanling, ca. $10 \mathrm{~km}$ SE from BFERS, at 800$1,100 \mathrm{~m}$ a.s.1. Here, much of the native vegetation is oak forest that has been clear-cut for farmland use at least 50-60 years ago. However, during the 1990 s, farming activities at the study area were aborted and the forest vegetation was restored; the former clear-cuts sprouted again and developed to oak coppice stands that can be regarded as young forests (coppice forests). The upland and valley areas at the Liyuanling area, on the other hand, are dominated by vitex shrubs (Vitex negundo var. heterophylla) and almond shrubs (Prunus armenica var. ansu). All of the coppice and shrub sites to study had a closed canopy, with the average tree height being 2-3 $\mathrm{m}$ (up to $5 \mathrm{~m}$ ).

Corresponding to variation in vegetation and soil moisture, eight plots were established in the core of each of the eight sites representing four habitat types: three upland forests (oak forest, larch plantation and pine plantation), two lowland forests (walnut forest and mixed broadleaved forest), one oak coppice forest, and two shrublands (dominated by vitex and almond shrubs). Each of the studied forests or shrublands 


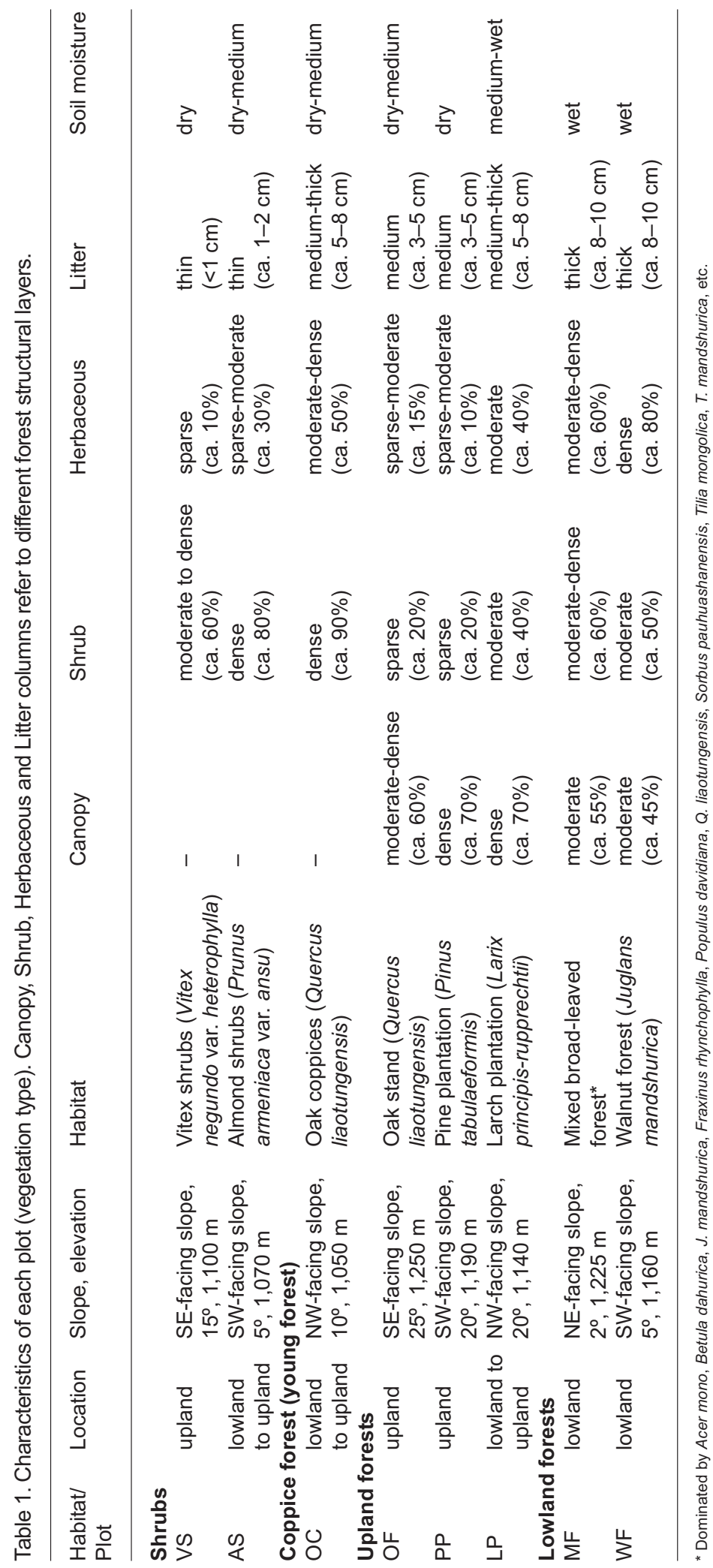


was over 4 ha, and the distance between adjacent sites was $1-2 \mathrm{~km}$. The characteristics of each site are shown in Table 1.

\subsection{Sampling}

Carabid beetles were captured using pitfall traps. Although pitfall traps are biased to active forms and are therefore not a direct measure of absolute population density, this method is useful in monitoring and assessing local population changes (Baars 1979, Spence \& Niemelä 1994). Traps were plastic beverage cups $(400 \mathrm{ml}$, depth $9 \mathrm{~cm}$, mouth diameter $7.5 \mathrm{~cm}$ ) filled with ca. $100 \mathrm{ml}$ of trapping fluid (vinegar : sugar : alcohol : water $10 \mathrm{ml}: 5 \mathrm{~g}: 5 \mathrm{ml}: 20 \mathrm{ml}$ ) (Yu et al. 2004). A small hole (diameter ca. $0.2 \mathrm{~cm}$ ) was drilled on each trap ca. $2.5 \mathrm{~cm}$ below the mouth to allow rain water to flow out. Because of that, some small carabids (such as Bembidion and Trechus) may have been lost from the samples. The collected specimens were preserved in $70 \%$ alcohol for identification.

Sampling was conducted from April to October (covering the growing season) in 1999. Pitfall traps were placed on two transects that were randomly arranged within each plot; however, the distance between adjacent transects was at least $100 \mathrm{~m}$. Each transect had 55 traps placed $2 \mathrm{~m}$ apart. The traps were serviced for every 3 days each month. We continued sampling using the same design in 2000 during May, July and September.

\subsection{Data analysis}

The activity density of carabids in different plots (habitats) was visually examined using the average number (standardized catches to 100 trapdays) of beetles captured per plot * trapping day.

Species diversity was calculated with Shannon-Wiener information index (Pielou 1975):

$H^{\prime}=-\sum_{i=1}^{s} P_{i} \ln P_{i}$

where $P_{i}$ is the proportion of the sample represented by $i^{\text {th }}$ species $(i=1-S)$. Equitability was represented by $J=H^{\prime} / H_{\text {max }}$ (Pielou 1975). Species richness $(S)$ was the number of species for samples with one or more individuals (Pielou 1975).

After logarithmic transformation, Detrended Correspondence Analysis (DCA) was applied to compare the community structure among different sites (Pielou 1984) using the PAST package (Hammer et al. 2001). Associations between abundant species were analyzed with non-parametric Spearman correlation (Sokal \& Rohlf 1981) using SPSS (1997).

\section{Results}

\subsection{Species richness and diversity}

Forty-one species in 14 genera of carabids were collected (Table 2). Four species, each accounting for $>10 \%$ of the total catch, were considered dominant: Carabus manifestus, Carabus crasseculptus, Pterostichus acutidens and Pterostichus subovatus. These species altogether accounted for $62 \%$ of the total catch. Two other species, viz. Pristosia sp.1 and Reflexiphodrus refleximargo, accounted for $8 \%$ and $7 \%$ of total specimens, respectively. All the other species collected represented $<5 \%$ of the total catch.

In both years, the lowland forest hosted more species than did the other habitat types, whereas the shrubland sites had fewer species than the other habitat types. Moreover, diversity was highest in the coppice forests and lowest in the shrub sites. The catches varied species specifically among the studied habitat types and between the two years. However, in terms of carabid species abundances, the catches for both years were more even in coppice forests than in the other habitat types (Table 3).

\subsection{Carabid community similarities among the studied habitats}

The DCA indicated strong clusterings of habitat types over the two years (Fig. 1). Based on the occurrence and abundance of carabid assemblages, two shrub sites had similar carabid assemblages within each year; on the other hand, the other six (all forested) sites including five mature forests and 1 coppice forest formed another cluster of 
Table 2. Ecological distribution of 41 species of carabid beetles collected in pitfall traps, 1999-2000. The species are classified into four types.

\begin{tabular}{|c|c|c|c|c|c|c|c|c|c|c|}
\hline \multirow[t]{2}{*}{ Species } & \multicolumn{2}{|c|}{ Shrubs } & \multirow{2}{*}{$\begin{array}{l}\text { Coppice } \\
\text { OC }\end{array}$} & \multicolumn{3}{|c|}{$\begin{array}{l}\text { Upland } \\
\text { forests }\end{array}$} & \multicolumn{2}{|c|}{$\begin{array}{l}\text { Lowland } \\
\text { forests }\end{array}$} & \multirow[t]{2}{*}{ Total } & \multirow{2}{*}{$\begin{array}{c}\text { Per- } \\
\text { cent } \\
(\%)\end{array}$} \\
\hline & VS & AS & & PP & OF & LP & WF & $\mathrm{MF}$ & & \\
\hline \multicolumn{11}{|l|}{ Habitat generalists } \\
\hline Carabus smaragdinus & 22 & 51 & 67 & 10 & 4 & 2 & 12 & 1 & 169 & 4.01 \\
\hline Carabus vladimirskyi & 11 & 41 & 6 & 8 & 7 & 8 & 5 & 1 & 87 & 2.06 \\
\hline Pristosia sp. 3 & - & 4 & 6 & - & 4 & 4 & 21 & 5 & 44 & 1.04 \\
\hline \multicolumn{11}{|l|}{ Forest generalists } \\
\hline Carabus manifestus & 8 & 1 & 152 & 42 & 233 & 355 & 229 & 68 & 1088 & 25.79 \\
\hline Reflexiphodrus refleximargo & - & - & 27 & 44 & 39 & 122 & 31 & 20 & 283 & 6.71 \\
\hline Pterostichus acutidens & - & 1 & 75 & - & 81 & 147 & 5 & 190 & 499 & 11.83 \\
\hline Pterostichus subovatus & - & 1 & 52 & 1 & 106 & 257 & 8 & 50 & 475 & 11.26 \\
\hline Pristosia sp.1 & 1 & 13 & 66 & 4 & 42 & 134 & 13 & 56 & 329 & 7.80 \\
\hline Pterostichus fortipes & 5 & 6 & 39 & 9 & 32 & 1 & 33 & 5 & 130 & 3.08 \\
\hline Carabus scultipennis & - & 4 & 36 & 5 & 29 & 8 & 25 & - & 107 & 2.54 \\
\hline Carabus crasseculptus & - & - & 4 & 76 & 68 & 226 & 105 & 90 & 569 & 13.49 \\
\hline Carabus sui & - & - & 9 & 25 & 39 & 7 & 6 & 5 & 91 & 2.16 \\
\hline Pristosia sp.2 & - & 1 & 1 & 1 & 11 & - & 22 & 26 & 62 & 1.47 \\
\hline \multicolumn{11}{|l|}{ Forest specialists } \\
\hline Carabus canaliculatus & - & - & - & - & 2 & 12 & 1 & 1 & 16 & 0.38 \\
\hline Pterostichus interruptus & - & - & - & - & - & 18 & - & 3 & 21 & 0.50 \\
\hline Pterostichus adstrictus & - & - & - & - & 5 & - & - & 75 & 80 & 1.90 \\
\hline \multicolumn{11}{|c|}{ Shrub and coppice specialists } \\
\hline Carabus granulatus & - & 7 & 59 & - & - & 1 & 7 & - & 74 & 1.75 \\
\hline Carabus brandti & 10 & 3 & 10 & - & - & - & - & 1 & 24 & 0.57 \\
\hline \multicolumn{11}{|l|}{ Other species } \\
\hline Agonum nitidum & - & - & - & 2 & - & 1 & - & - & 3 & 0.07 \\
\hline Amara sp.1 & - & 1 & - & 1 & - & 1 & 1 & - & 4 & 0.09 \\
\hline Amara sp.2 & - & 1 & - & - & - & - & - & 2 & 3 & 0.07 \\
\hline Asaphidion sp. & - & - & - & 1 & - & - & - & - & 1 & 0.02 \\
\hline Badister pictus & - & - & - & - & - & - & - & 1 & 1 & 0.02 \\
\hline Bembidion sp.2 & - & - & - & - & - & 2 & - & - & 2 & 0.05 \\
\hline Carabus hemmeli & - & - & - & - & - & 1 & - & - & 1 & 0.02 \\
\hline Chlaenius posticalis & - & 1 & - & - & - & - & - & - & 1 & 0.02 \\
\hline Curtonotus sp.1 & - & - & - & - & - & - & - & 1 & 1 & 0.02 \\
\hline Curtonotus sp.2 & - & 1 & - & - & - & - & - & - & 1 & 0.02 \\
\hline Curtonotus sp.3 & - & - & - & - & - & 1 & - & - & 1 & 0.02 \\
\hline Curtonotus sp.4 & - & 1 & - & - & - & - & - & - & 1 & 0.02 \\
\hline Cymindis daimio & 6 & - & - & - & - & - & - & - & 6 & 0.14 \\
\hline Harpalus bungii & - & 1 & - & 1 & - & - & - & - & 2 & 0.05 \\
\hline Harpalus coreanus & - & 2 & - & - & - & - & - & - & 2 & 0.05 \\
\hline Harpalus crates & - & 5 & - & - & - & - & - & - & 5 & 0.12 \\
\hline Harpalus quadripunctatus & - & - & 1 & - & - & - & 1 & 4 & 6 & 0.14 \\
\hline Harpalus tinctulus & - & - & - & 2 & - & - & - & - & 2 & 0.05 \\
\hline Harpalus tschiliensis & - & 1 & - & - & - & - & - & - & 1 & 0.02 \\
\hline Notiophilus sp. & - & - & - & 7 & 5 & 3 & 3 & - & 18 & 0.43 \\
\hline Pristosia sp.4 & - & - & - & - & - & - & - & 1 & 1 & 0.02 \\
\hline Pterostichus laticollis & - & - & - & - & - & - & - & 7 & 7 & 0.17 \\
\hline Pterostichus microcephalus & - & - & 1 & - & - & - & - & - & 1 & 0.02 \\
\hline
\end{tabular}


Table 3. Carabid species richness, diversity and equitability in the studied vegetation types and during the two study years.

\begin{tabular}{|c|c|c|c|c|c|c|}
\hline \multirow[t]{2}{*}{ Habitat type } & \multicolumn{2}{|c|}{ Richness (S) } & \multicolumn{2}{|c|}{ Diversity $\left(H^{\prime}\right)$} & \multicolumn{2}{|c|}{ Equitability $(J)$} \\
\hline & 1999 & 2000 & 1999 & 2000 & 1999 & 2000 \\
\hline Shrubs & 14 & 7 & 1.90 & 1.37 & 0.79 & 0.74 \\
\hline Coppice forests & 16 & 14 & 2.28 & 2.23 & 0.82 & 0.84 \\
\hline Upland forests & 16 & 13 & 1.94 & 1.94 & 0.71 & 0.75 \\
\hline Lowland forests & 18 & 15 & 1.94 & 1.96 & 0.67 & 0.74 \\
\hline
\end{tabular}

sites, indicating rather similar carabid assemblages. However, they often showed remarkable variation in placing over the two-dimensional DCA space within the group of forested sites and between the two years (Fig. 1).

Among the six most abundant species, $C$. $m a$ nifestus, C. crasseculptus, $P$. subovatus and $P$. acutidens showed significant abundance correlations with each other. More specifically, P. subovatus was positively correlated with $C$. manifestus over the two years and and positively with C. crasseculptus in 2000. Reflexiphodrus refleximargo was positively correlated with the two above-listed Carabus species, and Pristosia sp.1 was positively correlated with the two Pterostichus species and Carabus manifestus in 2000 (Table 4).

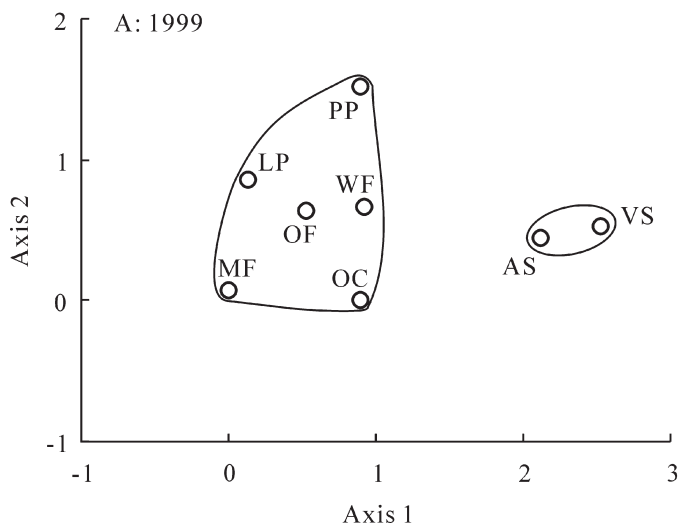

\subsection{Carabid distribution}

We regarded a species as being abundant if the catch was $>10$ individuals in at least one habitat type over the whole trapping season (on average more than one individual per collection) and if it comprised $>5 \%$ of all the beetles captured (modified from Niemelä et al. 1992). According to this rule of thumb and based on their occurrence among the habitats, we divided the 18 abundant species into four groups (Table 2).

\subsection{Seasonal activity}

The mean catches $(n / 100$ traps * day) with pooled carabids indicated a distinctive abundance peak in August in the vitex shrub sites (Fig. 2a), relatively even abundance from May to August in

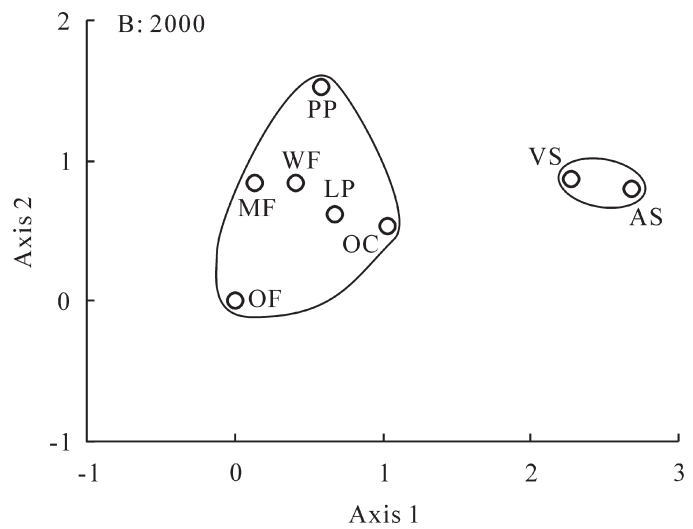

Fig.1. Detrended Correspondence Analysis for the carabid samples. Axes 1 and 2 respectively explain $37.4 \%$ and $16.4 \%$ of the total variation in 1999 and $38.1 \%$ and $8.8 \%$ in 2000 . Shrubs $=$ VS (vitex shrubs) and AS (almond shrubs); Coppice = OC (oak coppice); Upland forests = PP (pine plantation), OF (oak forest) and LP (larch plantation); Lowland forests $=$ WF (walnut forest) and MF (mixed broad-leaved forest). 
Table 4. Spearman rank correlation coefficients ( $p$ value) for the abundance of the six carabid species that made up $>5 \%$ of the total catch in 1999 and 2000 .

\begin{tabular}{lcllllr}
\hline Species & Year & $\begin{array}{l}\text { C. crasse- } \\
\text { culptus }\end{array}$ & P. subovatus & P. acutidens & \multicolumn{1}{l}{$\begin{array}{l}\text { R. reflexi- } \\
\text { margo }\end{array}$} & Pristosia sp. 1 \\
\hline C. manifestus & 1999 & $0.731(0.040)$ & $0.711(0.048)$ & $0.611(0.108)$ & $0.611(0.108)$ & $0.214(0.610)$ \\
& 2000 & $0.868(0.005)$ & $0.898(0.002)$ & $0.659(0.076)$ & $0.802(0.017)$ & $0.756(0.030)$ \\
C. crasseculptus & 1999 & & $0.461(0.251)$ & $0.657(0.077)$ & $0.639(0.088)$ & $-0.024(0.955)$ \\
& 2000 & & $0.800(0.017)$ & $0.630(0.094)$ & $0.861(0.006)$ & $0.691(0.058)$ \\
P. subovatus & 1999 & & & $0.849(0.008)$ & $0.545(0.162)$ & $0.602(0.114)$ \\
& 2000 & & & $0.859(0.006)$ & $0.614(0.105)$ & $0.908(0.002)$ \\
P. acutidens & 1999 & & & $0.392(0.337)$ & $0.587(0.126)$ \\
& 2000 & & & $0.319(0.441)$ & $0.975(<0.001)$ \\
R. refleximargo & 1999 & & & & $0.072(0.866)$ \\
& 2000 & & & & & $0.442(0.273)$ \\
\hline
\end{tabular}

the almond shrub sites (Fig. 2b), and a July peak in all of the forest sites (Fig. 2c-g) except in the walnut forest, where the mean catches remained high from June to August (Fig. 2h).

At the species level, Carabus manifestus had two peaks: in the early season and middle-late season (Fig. 3a), whereas Carabus crasseculptus, P. acutidens, P. subovatus and Pristosia sp. 1. showed a main peak in the middle season (Fig. 3b-e). Finally, Reflexiphodrus refleximargo showed a similar abundance pattern as $\operatorname{did} C$. $m a-$ nifestus (Fig. 3f).

\section{Discussion}

\subsection{Species abundance and composition}

Our results indicate that although carabid species-level responses to habitat type varied between the two years, carabid assemblages of the five mature forests and the coppice forest were more similar to each other than to those in the two shrubland sites (Fig. 1). This result was consistent with the microclimate and edaphic characteristics of each habitat. As indicated in Table 1, the two
Fig. 2. Seasonal activitydensity of carabid beetles in the eight habitat types in 1999. - a. Vitex shrubs. - b. Almond shrubs. - c. Oak coppice. - d. Oak forest. - e. Pine plantation. $-f$. Larch plantation. - g. Mixed broad-leaved forest. $-\mathrm{h}$. Walnut forest.
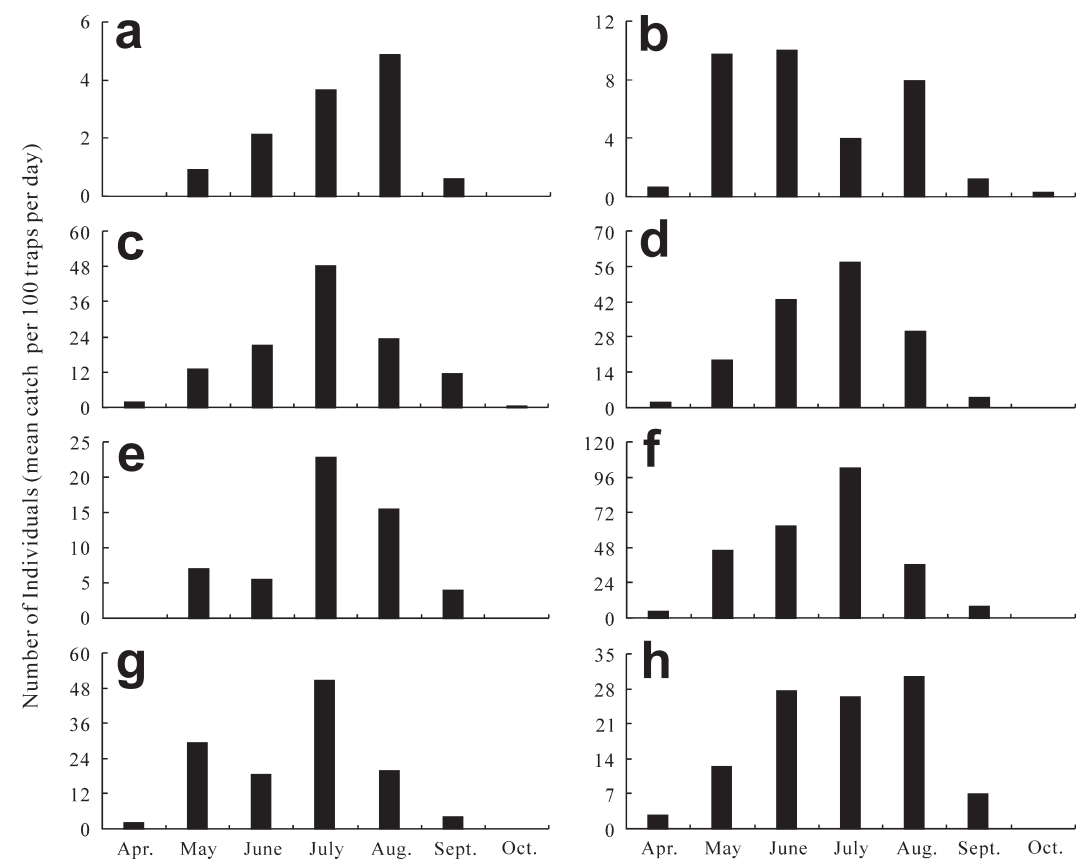


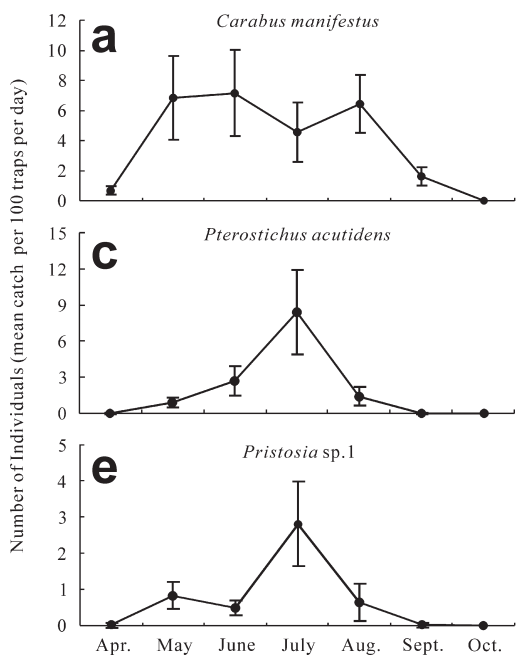

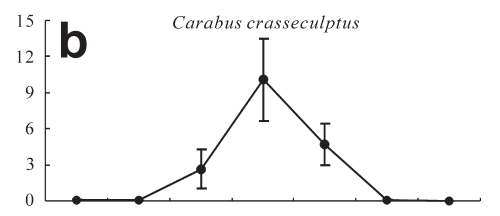
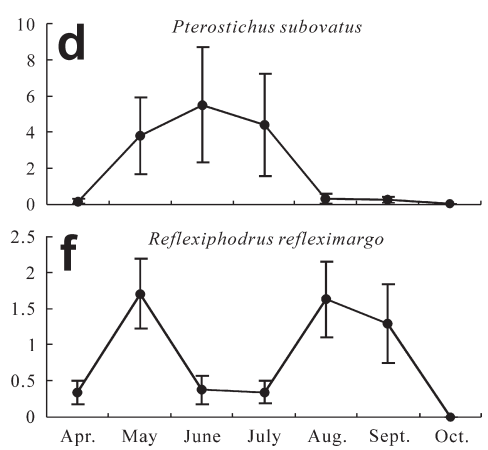

Fig. 3. Mean catch $( \pm$ S.E.) of the six most abundant species that all comprised $>5 \%$ of the total catch in 1999. shrubland sites were both characterized by dry soil, thin leaf-litter layer, and sparse herbs. Contrary to this, the six forested habitats shared very different characteristics: moist soil, thick leaf litter, and moderate to dense shrub layer. Thus, the differences between forests and shrub sites in terms of habitat characteristics might determine the distribution of carabids over the whole study area. Our previous research on Carabus assemblages in the same study area also supports this hypothesis (Yu et al. 2002).

Our results also indicated that the coppice forest had higher diversity and equitability than had mature forests and shrub sites, and that the forested sites with closed canopy supported more carabid species and individuals than did the two shrub sites that were relatively open. Also this result can be explained by the edaphic characteristics of different habitats. Except for the aspects similar to mature forests, the oak coppice stand had lower canopy cover and higher structural heterogeneity than did the mature forests; the heterogeneity might contribute to the higher diversity of carabid assemblage there. Jennings et al. (1986) also suggested that carabids can be commonly associated with closed than open habitats.

\subsection{Carabid distribution and spatial scale}

Carabids responded to habitat structural differences in varying ways depending on the spatial scale in question. As was expected from earlier work (Lindroth 1961-1969, Thiele 1977), carabids were associated with broad habitat types, such as forest and hrub habitats. However, most of 18 abundant species were common in several habitats, and just a few were restricted to either forest or shrub sites. On the finer scale, our results also showed that forests are patchy environments for carabids, as there were some species restricted to only one or two habitat types studied. Niemelä et al. (1992) reported that carabid species may have abundance variation among different habitat types and that most of the species are habitat specialists in this sense; they also suggested that soil moisture can be an important determinant of carabid habitat associations. However, we found a rather similar habitat selection among carabid species, as most of the carabids appeared to be forest generalists. This difference may be attributed to differences in edaphic characteristics among habitats (Niemelä et al. 1992). There are only a few detailed reports on carabid fauna among different habitats of North China; therefore, we could not directly compare the details of carabid distributions. Thus, further research on carabid fauna in this respect are clearly needed.

\subsection{Temporal distribution}

In extra-tropical regions, the factors regulating the life cycles of carabid species may include temperature and photoperiodicism (Thiele 1977, 


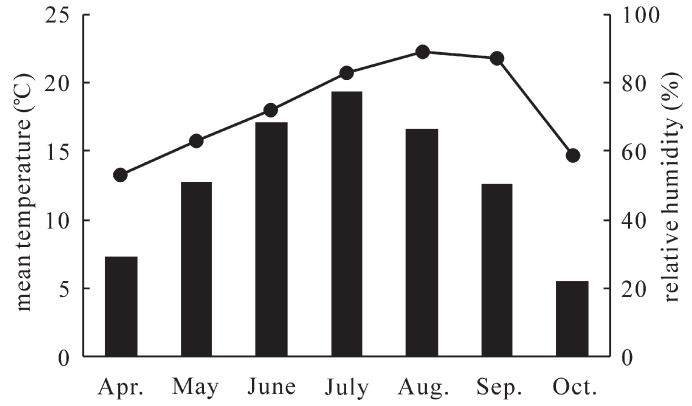

Fig. 4. Monthly mean temperature $\left({ }^{\circ} \mathrm{C}\right)$ and relative humidity (\%) in the studied region in 1999. Meteorological data were collected from Beijing Forestry Ecosystem Research Station (4000' N, 115²6' E, 1,200 $\mathrm{m}$ a.s.I.). Columns $=$ temperature, curve $=$ relative humidity.

Sota 1985, 1994, Lövei \& Sunderand 1996), as suggested by our finding on the distinctive seasonal activity peaks of carabids. In carabids, these peaks usually coincide with reproduction (Niemelä et al. 1989, 1992). Most species in our study showed prominent abundance peaks in the middle season; moreover, two abundant species showed two peaks during the growing season. This result seems to contradict with the singlepeak pattern (corresponding to spring or autumn) observed in North America and Europe (Epstein \& Kulman 1990, Niemelä et al. 1992). Niemelä et al. (1989) also reported a flexible seasonal rhythm for several dominant carabid species in the southern Finnish taiga. Perhaps the short growing season in high latitudes forces carabids to breed in early summer to ensure that their offspring have enough time to reach the adult stage before over-wintering (Niemelä et al. 1989, Sota 1994). The middle-season activity peak in more southern latitudes, reported here, may be associated with optimal temperature and soil moisture rather than with the length of the growing season. The relative humidity, associated with soil moisture, is always relatively high during July to September $(>80 \%)$, as is the mean temperature during June to August $\left(+16 \ldots+19^{\circ} \mathrm{C}\right.$; see Fig. 4). Thus, the optimal conditions for carabids may occur between July and August, and moisture and temperature might thus determine the seasonal dynamics of carabids in our study region.

Acknowledgements. We thank Dr. Hong-Bin Liang (Institute of Zoology) for assistance in species identification. We also thank Dr. Ke-Ping Ma, Xian-Ming Gao, Wei Wang, Qing-Kang Li and Ms. Wen-Jie Yan (Institute of Botany), our colleagues in Research Station of Institute of Zoology, for field and technical assistance, and providing meteorological data. We also acknowledge Dr. Scott L. Bearer (Center for Systems Integration and Sustainability, Michigan State University) for linguistic comments on the manuscript, Dr. Jari Niemelä and Dr. Teiji Sota for kindly sending reprints. This study was supported partly by the State Key Basic Research and Development Plan from the Chinese Ministry of Science and Technology (G2000046801), the National Natural Science Foundation of China (30570215), a grant for the senior author (no. D/3684-1) of the International Foundation for Sciences (I. F. S., Stockholm, Sweden) and the National Science Fund for Fostering Talents in Basic Research (NSFCJ0030092).

\section{References}

Addicott, J. F., Aho, J. M., Antolin, M. F., Padilla, D. K., Richardson, J. S. \& Soluk, D. A. 1987: Ecological neighborhoods: scaling environmental patterns. Oikos 49: 340-346.

Baars, M. A. 1979: Catches in pitfall traps in relation to mean densities of carabid beetles. - Oecologia 41: 25-46.

Chen, L.-Z. \& Huang, J.-H. 1997: The study on structure and function of forest ecosystem in warm temperate zone. - Science Press, Beijing. 295 pp. [In Chinese with English abstract.]

Didham, R. K., Ghazoul, J., Stork, N. E. \& Davis, A. J. 1996: Insects in fragmented forests: a functional approach. - Trends in Ecology and Evolution 11: 255260.

Epstein, M. E. \& Kulman, H. M. 1990: Habitat distribution and seasonal occurrence of carabid beetles in Eastcentral Minnesota. - American Midland Naturalist 123: 209-225.

Esau, K. L. \& Peters, D. 1975: Carabidae collected in pitfall traps in Iowa cornfields, fencerows, and prairies. — Environmental Entomology 4: 509-513.

Hammer, Ø., Harper, D. A. T. \& Ryan, P. D. 2001: PAST: paleontological statistics software package for education and data analysis. - Palaeontologia Electronica 4: 9.

Hu, D.-X., Yu, Z.-R., Han, C.-R., He, J.-H. \& Paoletti, M. G. 1998: Community structure of carabids and spiders in agricultural landscape in Qian Jiang, Hubei Province. - Acta Entomologica Sinica (Suppl.) 41: 91-97. [In Chinese with English abstract.]

Huang, T.-L. 1990: Catalogus of Carabidae (Coleoptera) from China (1933-1988). - Sichuan Science and Technology Publishing House, Chengdu. 119 pp. [In Chinese with English abstract.]

Jennings, D. T., Houseweart, M. W. \& Dunn, G. A. 1986: Carabid beetles (Coleoptera: Carabidae) associated with strip clear-cut and dense spruce-fir forest of 
Maine. - Coleopterists Bulletin 40: 251-263.

Kim, C. G., Zhou, H.-Z., Imura, Y., Tominaga, O., Su, Z. H. \& Osawa, S. 2000: Pattern of morphological diversification in the Leptocarabus ground beetles (Coleoptera: Carabidae) as deduced from mitochondrial ND5 gene sequences. - Molecular Biology and Evolution 17: 137-145.

Liebherr, J. \& Marhar, J. 1979: The carabid fauna of the upland oak forest in Michigan: survey and analysis. Coleopterists Bulletin 33: 183-197.

Lindroth, C. H. 1961-1969: The ground beetles (Carabidae excl. Cicindelidae) of Canada and Alaska. - Opuscula Entomologicae (Suppl.) 20: 1-200; 24 : 201-408; 29: 409-648; 33: 649-944; 34: 945-1192.

Lövei, G. L. \& Sunderland, K. D. 1996: Ecology and behavior of ground beetles (Coleoptera: Carabidae). Annual Review of Entomology 41: 231-256.

Niemelä, J. \& Halme, E. 1992: Habitat associations of carabid beetles in fields and forests on Åland Islands, SW Finland. - Ecography 15: 3-11.

Niemelä, J. \& Spence, J. R. 1994: Distribution of forest dwelling carabids (Coleoptera): spatial scale and the concept of communities. - Ecography 17: 166-175.

Niemelä, J., Spence, J. R. \& Spence, D. H. 1992: Habitat associations and seasonal activity of ground-beetles (Coleoptera: Carabidae) in Central Alberta. - Canadian Entomologist 124: 521-540.

Niemelä, J., Haila, Y., Halme, E., Lahti, T., Pajunen, T. \& Punttila, P. 1988: The distribution of carabid beetles in fragments of old coniferous taiga and adjacent managed forest. - Annales Zoologici Fennici 25: 107119.

Niemelä, J., Haila, Y., Halme, E., Pajunen, T. \& Punttila, P. 1989: The annual activity cycle of carabid beetles in southern Finnish taiga. - Annales Zoologici Fennici 26: $35-41$.

Pielou, E. C. 1975: Ecological diversity. — Wiley, New York. $165 \mathrm{pp}$.

Pielou, E. C. 1984: The interpretation of ecological data. — Wiley, New York. 263 pp.

Sokal, R. R \& Rohlf, F. J. 1981: Biometry. - W. H. Freeman, New York. 859 pp.

Sota, T. 1985: Life history patterns of Carabid beetles belonging to the subtribe Carabina (Coleoptera, Carabidae) in the Kinki District, Western Japan. - Kontyu (Tokyo) 53: 370-378.

Sota, T. 1994: Variation of carabid life cycles along climatic gradients: an adaptive perspective for life-history evolution under adverse conditions. - In: Danks, H. V. (ed.), Insect life-cycle polymorphisms: 99-112. Kluwer, Dordrecht. 396 pp.

Spence, J. R. \& Niemelä, J. 1994: Sampling carabid assemblages with pitfall traps: the madness and the method. - Canadian Entomologist 126: 881-894.

SPSS 1997: SPSS base 7.5 for Windows user's guide. SPSS Inc, Chicago. 883 pp.

Su, Z. H., Imura, Y., Zhou, H.-Z., Okamoto, M. \& Osawa, S. 2003: Mode of morphological differentiation in the Latitarsi-ground beetles (Coleoptera, Carabidae) of the world inferred from a phylogenetic tree of mitochondrial ND5 gene sequences. - Genes \& Genetic Systems 78: 53-70.

Su, Z. H., Imura, Y., Okamoto, M., Kim, C. G., Zhou, H.Z., Paik, J. C. \& Osawa, S. 2004: Phylogeny and evolution of Digitulati ground beetles (Coleoptera, Carabidae) inferred from mitochondrial ND5 gene sequences. - Molecular \& Phylogenetic Evolution 30: 152-166.

Thiele, H.-U. 1977: Carabid beetles in their environments. — Springer-Verlag, Berlin. 369 pp.

Wallin, H. \& Ekbom, B. S. 1988: Movements of carabid beetles (Coleoptera: Carabidae) inhabiting cereal fields: a field tracing study. — Oecologia 77: 39-43.

Wiens, J. A. 1976: Population responses to patchy environments. - Annual Review of Ecology and Systematics 7: 81-120.

Wiens, J. A. 1989: Spatial scaling in ecology. — Functional Ecology 3: 385-397.

Yu, P.-Y. 1980: Preliminary study on Chinese carabid beetles as grain crop pests. - Entomotaxonomia 2: 8184. [In Chinese with English abstract.]

Yu, X.-D., Luo, T.-H. \& Zhou, H.-Z. 2004: Carabus (Coleoptera: Carabidae) assemblages of native forests and non-native plantation in Northern China. - Entomologica Fennica 15: 129-137.

Yu, X.-D., Zhou, H.-Z. \& Luo, T.-H. 2001: Habitat distribution and species diversity of Carabus and Cychrus in Shennongjia Nature Reserve, Hubei Province. Biodiversity Science 9: 214-221. [In Chinese with English abstract.]

Yu, X.-D., Zhou, H.-Z. \& Luo, T.-H. 2002: Distribution patterns and their seasonal changes of Carabus beetles in Dongling Mountain Region near Beijing. - Acta Ecologica Sinica 22: 1724-1733. [In Chinese with English abstract.] 